\title{
SURVIVAL OF LISTERIA MONOCYTOGENES IN LOW ACID ITALIAN SAUSAGE PRODUCED UNDER BRAZILIAN CONDITIONS
}

\author{
Roberto Degenhardt ${ }^{1}$; Ernani S Sant ${ }^{`}$ Anna $^{1 *}$ \\ ${ }^{1}$ Departamento de Ciência e Tecnologia de Alimentos, Centro de Ciências Agrárias, Universidade Federal de Santa Catarina, \\ Florianópolis, SC, Brasil
}

Submitted: June 19, 2006; Returned to authors for corrections: September 04, 2006; Approved: October 20, 2006.

\begin{abstract}
Dry sausages have been considered ready-to-eat products with low risk of causing listeriosis due to the hurdles created during the manufacturing process such as low $\mathrm{pH}$ and $\mathrm{a}_{\mathrm{w}}$, high salt concentration and presence of lactic acid bacteria (LAB). However, several studies have detected survival of Listeria monocytogenes in these products and also shown that process parameters, LAB and L. monocytogenes strains directly influence the results. In this work, survival of the pathogen in sausages prepared with three different formulations (one standard formulation, one formulation added of Lactobacillus plantarum and one added of $2 \%$ sodium lactate), using the manufacturing process usually employed in Brazil, was evaluated. Naturally contaminated sausages presented a small increase in the counts of $L$. monocytogenes in the first days of the process, followed by a gradual decrease until the end of the process. In experimentally contaminated samples containing $L$. plantarum, the reduction of counts of $L$. monocytogenes during processing was considerable, but there wasn't significant differences between the treatments.
\end{abstract}

Key words: Listeria monocytogenes, Lactobacillus plantarum, Fermented dry sausage, Survival, Brazilian salami

\section{INTRODUCTION}

Salamis are dry fermented sausages manufactured with pork, pork fat, salt, ripening adjuvants and spices. This kind of sausage is considered a ready-to-eat product, because it does not require any thermal treatment befora comsumption $(5,10$, $18,22)$. The manufacturing process varies according to the production region and regional consumer preferences $(1,8,25,28)$.

Fermented meat products have been considered safe products (23). During fermentation the acid lactic bacteria (LAB) uptake of the oxygen in the raw matter, decreasing the redox potential and turning nitrite into a more effective tool to prevent the growth of aerobic spoilage and pathogenic bacteria. In addition, low $\mathrm{pH}$ causes a decrease in the protein water holding capacity, accelerating sausage dehydration and leading to low $\mathrm{a}_{\mathrm{w}}$ and high $\mathrm{NaCl}$ concentration in the final product $(30,31)$.

Listeria monocytogenes has been considered the most important foodborne pathogen due to the high death rate in risk groups (29). During fermentation and drying, the count of L.monocytogenes in sausages tends to decrease because of a set of hurdles created in the manufacturing process $(8,30)$. However, L. monocytogenes is often isolated from fermented meat products, due to the capability to survive to the adverse conditions of this type of product $(2,3,12,33)$.

Due to the lack of studies on the behavior of L. monocytogenes in Brazilian fermented meat products, the aim of this study was to evaluate the survival of $L$. monocytogenes in low acid Italian sausages produced under Brazilian conditions and in the presence of intentionally added inhibitory compounds.

\section{MATERIALAND METHODS}

Raw meat, spices and ingredients were obtained in a pork slaughter and industrial plant in Videira-SC, Brazil. The commercial strain of Lactobacillus plantarum (Holbac $100^{\mathrm{TM}}$ ) was supplied by Danisco Brasil LTDA.

*Corresponding Author. Mailing address: Dep. de Ciência e Tecnologia de Alimentos - Centro de Ciências Agrárias - Universidade de Santa Catarina Rod. Ademar Gonzaga, 1346 - Itacorubi 88034-001 Florianópolis, SC - Brasil. Tel.: (48) 331-5372 ou (48) 331-9943. E-mail: ernanis@cca.ufsc.br 


\section{Preparation of the inoculum}

The L. monocytogenes strain ATCC 7644 (OXOID C3970L) was resuspended in Brain Heart Infusion - BHI (MERCK 1.10493 ) and incubated overnight at $36^{\circ} \mathrm{C}$. The culture was transferred to Trypticase Soy Agar - TSA (OXOID CM 131) and kept under refrigeration. For usem, the cultures were transfered to $\mathrm{BHI}$ broth, incubated overnight at $36^{\circ} \mathrm{C}$, and then submitted ot decimal dilutions in $0.85 \%$ sterile saline. The diluted culture containing $10^{4} \mathrm{UFC} \mathrm{mL}{ }^{-1}$ was kept under refrigeration until the moment of use.

\section{Preparation of sausages}

Three different formulations of sausages were prepared: one standard formulation with no inhibitor additive, one formulation with Lactobacillus plantarum and one with $2 \%$ sodium lactate. Each formulation was performed in two batches: one control batch and one added of Listeria monocytogenes ATCC 7644 (Table 1). Assays were performed in duplicates.

Table 1. Codification of sausage batches prepared to evaluate survival of Listeria monocytogenes.

\begin{tabular}{|c|c|c|}
\hline Formulation & Batches & Batch description \\
\hline \multirow[t]{2}{*}{ A - Standard } & A1 & Raw mixture standard \\
\hline & A2 & $\begin{array}{l}\text { Raw mixture standard }+ \\
\text { L. monocytogenes }\end{array}$ \\
\hline \multirow[t]{2}{*}{$\begin{array}{c}\mathrm{B}-\text { Lactobacillus } \\
\text { plantarum }\end{array}$} & B1 & Raw mixture $+L$. plantarum \\
\hline & B2 & $\begin{array}{l}\text { Raw mixture }+L \cdot \text { plantarum } \\
+L . \text { monocytogenes }\end{array}$ \\
\hline \multirow[t]{2}{*}{ C - Sodium Lactate } & $\mathrm{Cl}$ & Raw mixture + Sodium Lactate \\
\hline & $\mathrm{C} 2$ & $\begin{array}{l}\text { Raw mixture }+ \text { Sodium Lactate } \\
+ \text { L. monocytogenes }\end{array}$ \\
\hline
\end{tabular}

The six batches (A1, A2, B1, B2, C1, C2) were prepared with the same raw components: pork meat $(74.9 \%)$, pork fat $(16.0 \%)$, salt (2.8\%), curing salt (sodium nitrate and nitrite) $(0.3 \%)$, sodium eritorbate $(0.04 \%)$, monosodium glutamate $(0.25 \%)$, maltodextrin $(0.5 \%)$, dried milk (4.0\%), glucono delta-lactone (GDL) $(1.2 \%)$ and Staphylococcus carnosus (BACTOFERM SB 61 - Chr. Hansen) (0.025\%).

The dry sausages were prepared in two steps. In the first step, a mixture was prepared in a cutter (MADO Granrant ${ }^{\circledR}$ ) with pork (15\%), salt (10\% of the entire content), frozen pork fat, ground with the half graining desired. In the second step, $L$. monocytogenes inoculum (A2, B2, C2 batches), cultures, spices and additives were added and the cutting continued until the particles were about $5 \mathrm{~mm}$ in diameter. Then, the minced mixture was stuffed (stuffer Heinrich Frey Maschinenbau GmmH Henry $20 \AA)$ in collagen casings ( $43 \mathrm{~mm}$ ), making pieces of 350$400 \mathrm{~g}$. Sausages were hung in a climate-controlled chamber for fermentation and drying.

Batches B1 and B2 were added of $0.025 \%$ Holbac $100 \AA$ (DANISCO) dissolved in $50 \mathrm{~mL}$ of distilled water. Batches $\mathrm{C} 1$ and $\mathrm{C} 2$ were added of $2.0 \%$ sodium lactate (Purasal - PURAC).

\section{Technological parameters}

Fermentation and drying were performed in a climatecontrolled chamber $($ Reich $\AA)$. For ripening, the chamber temperature and relative humidity were $22-24^{\circ} \mathrm{C}$ and $94-98 \%$, respectively, during $48 \mathrm{~h}$. The conditions for fermentation and drying up to 28 days are shown in Table 2 .

Table 2. Technological parameters for ripening, fermentation and drying of sausages

\begin{tabular}{ccc}
\hline Day & Temperature $\left(\mathrm{C}^{\circ}\right)$ & Relative Umidity $(\mathrm{RU} \%)$ \\
\hline 1,2 & $22-24$ & $94-98$ \\
3 & $20-22$ & $92-96$ \\
4 & $18-20$ & $90-94$ \\
5 & $16-18$ & $88-92$ \\
6 & $12-14$ & $85-90$ \\
$7-28$ & $12-14$ & $82-87$ \\
\hline
\end{tabular}

\section{Microbiological analysis}

Samples were taken from each batch after 0, 7, 14, 21 and 28 days of production. Portions of $25 \mathrm{~g}$ were homogenized with $225 \mathrm{~mL}$ of Buffered Peptone Water (OXOID CM 509) using a stomacher (model 400, Seward Medical, England). Further decimal dilutions were prepared with Buffered Peptone Water (OXOID CM 509). The counts of L. monocytogenes were determined by the most probable number dilution technique (MPN), (3 tubes each at - 1,0 g, 0,1 g, 0,01 g, 0,001 g e 0,0001 g inocula), using Modified Listeria Enrichment Broth (ACUMEDIA 7409A) for pre-enrichment $\left(24 \mathrm{~h}\right.$ at $30^{\circ} \mathrm{C}$ ), Fraser broth (ACUMEDIA 7502A) for a second enrichment (48 $\mathrm{h}$ at $35^{\circ} \mathrm{C}$ ) and Listeria selective agar (ALOA - BIOLIFE 404605) $\left(24-48 \mathrm{~h}\right.$ at $35^{\circ} \mathrm{C}$ ) for isolation (32). Three to five typical colonies of $L$. monocytogenes were submitted to catalase test, motility by microscopy (32), CAMP test (Tryptic Soy Agar - OXOID CM 131 added of sheep blood - NEWPROV), acid production from L(+)-rhamnose (Phenol-red Broth Base - MERCK 1.10987, L(+)-rhamnose - MERCK 1.04736) and Listeria O Antisera Types 1,4 (DIFCO 223021). LAB were counted in MRS Agar (OXOID CM 361) incubated att $30^{\circ} \mathrm{C}$ for 48 to $72 \mathrm{~h}$ in microaerophilic conditions (26). Typical colonies were confirmed by catalase reaction. 


\section{Chemical analsysis}

Sausage samples were ground and homogeneized in adequate miller. $\mathrm{pH}$ was measured inserting the spear electrode of a pH meter (model 410 - 060547, ORION) into the samples. Aw was measured calculating water and salt percentages according to Krispien, Rödel and Leinster (15). Moisture was determined by gravimetry at $105^{\circ} \mathrm{C}$ until constant weight and chloride was determined by a mercurometric method (4).

\section{Statistical analysis}

Three repetitions of each batch were carried through. The results of Listeria monocytogenes were expressed as log NMP $\mathrm{g}^{-1}$ and the counts of LAB were expressed as $\log \mathrm{CFUg}^{-1}$. The data of $\mathrm{pH}, \mathrm{Aw}, \mathrm{NMP}$ of Listeria monocytogenes and $\mathrm{LAB}$ counts were submitted to analysis of variance (ANOVA) using Statistica software version 6.0. Tukey's Test was applied when the detected difference among the values was significant with $5 \%$ of significance $(\mathrm{p}<0.05)$.

\section{RESULTS AND DISCUSSION}

\section{pHand $\mathrm{a}_{\mathrm{w}}$}

The differences in $\mathrm{pH}$ and $\mathrm{Aw}$ for the three formulations (Table 3) were not significant $(\mathrm{P}>0.05)$. The decrease of $\mathrm{pH}$ until the $14^{\text {th }}$ day, a rise in the $21^{\text {st }}$ day and then a stabilization up to the $28^{\text {th }}$ day in all formulations were considered normal in the Brazilian salamis manufacturing process. The decrease is a consequence of the the activity of naturally occurring LAB and the subsequent rise is caused by proteolysis and lipolysis, probably performed by yeasts, also responsible for the development of the maturation characteristic flavor $(19,29,34)$.

Aw reduction during ripening in all formulations was similar, but from the $14^{\text {th }}$ day on, the Aw decrease in formulations $\mathrm{C} 1$ and $\mathrm{C} 2$ was more intense than in the other formulations. This fact can be explained by the humectant effect of the sodium lactate, which increases the water retention capacity causing the reduction of Aw (24).

\section{LAB Counts}

Counts of LAB (Table 3) ranged from 6.0 to $7.0 \log \mathrm{CFUg}^{-1}$, with no differences between the batches ( $p>0.05$ ), except of batch A1. Except for batches B1 and B2, the LAB detected in the other batches originated from the raw material from the production site.

\section{Survival of L. monocytogenes in naturally contaminated samples}

As shown in Fig. 1, L. monocytogenes counts in naturally contamined sausages (batches A1, B1 and C1) were very low, as already reported by Peccio (20) and Silva (27). The $L$. monocytogenes curves for batches A1 e B1 were different from those of the other batches. In batch B1, the initial count was higher than in batches $\mathrm{A} 1$ and $\mathrm{C} 1$, and the difference between the beginning and the end of the process was $2.42 \mathrm{log}$. For this batch, a constant decrease until the 14th day was observed, followed by a small increase at the 21 st day and a rapid decrease at the 28th day. In batch A1, the difference in counts between the beginning and the end of the process was only $0.04 \mathrm{log}$. In this batch, the counts increased until the $7^{\text {th }}$ day, and decreased afterwards, with a very small increase at day 28 . Campani et al. (6) presented similar results when comparing the effect of two $L$. plantarum strains, one bacteriocin-producing and another nonbacteriocin-producing, on the survival of $L$. monocytogenes during the manufacture of Italian sausage. The growth of $L$. monocytogenes in batch A1 in the first week may be a response to the gradual acidity increase and lack of hurdles, which is expected in strains adapted to environmental stress $(21,35)$.

In batch $\mathrm{C} 1$, there ere no L. monocytogenes counts, certainly because raw material contamination was under the detection limit of the analytical method.

Table 3. LAB counts, $\mathrm{pH}$ and Aw values during the ripening and maturation of sausages.

\begin{tabular}{|c|c|c|c|c|c|c|c|c|c|c|c|c|c|c|c|}
\hline \multirow[t]{2}{*}{ Batch } & \multicolumn{3}{|c|}{ Day 0} & \multicolumn{3}{|c|}{ Day 7} & \multicolumn{3}{|c|}{ Day 14} & \multicolumn{3}{|c|}{ Day 21} & \multicolumn{3}{|c|}{ Day 28} \\
\hline & $L A B$ & $\mathrm{pH}$ & $\mathrm{A}_{\mathrm{w}}$ & $L A B$ & $\mathrm{pH}$ & $\mathrm{A}_{\mathrm{w}}$ & $L A B$ & $\mathrm{pH}$ & $\mathrm{A}_{\mathrm{w}}$ & $L A B$ & $\mathrm{pH}$ & $\mathrm{A}_{\mathrm{w}}$ & $L A B$ & $\mathrm{pH}$ & $\mathrm{A}_{\mathrm{w}}$ \\
\hline $\mathrm{A} 1$ & 5.00 & 5.61 & 0.958 & 5.97 & 4.99 & 0.938 & 6.88 & 4.93 & 0.916 & 6.35 & 5.08 & 0.895 & 5.80 & 5.16 & 0.892 \\
\hline A2 & 5.48 & 5.74 & 0.959 & 6.43 & 5.03 & 0.941 & 6.80 & 4.82 & 0.917 & 6.37 & 5.12 & 0.901 & 6.40 & 5.12 & 0.897 \\
\hline B1 & 6.21 & 5.62 & 0.958 & 6.87 & 5.08 & 0.939 & 7.34 & 4.89 & 0.917 & 7.05 & 5.03 & 0.898 & 6.95 & 5.17 & 0.895 \\
\hline B2 & 6.17 & 5.74 & 0.958 & 6.85 & 5.07 & 0.940 & 7.24 & 4.91 & 0.917 & 7.03 & 5.06 & 0.899 & 6.78 & 5.19 & 0.896 \\
\hline $\mathrm{Cl}$ & 6.00 & 5.60 & 0.959 & 6.74 & 5.06 & 0.937 & 6.60 & 4.76 & 0.915 & 6.40 & 5.07 & 0.885 & 6.00 & 5.19 & 0.883 \\
\hline $\mathrm{C} 2$ & 6.26 & 5.36 & 0.959 & 6.98 & 5.08 & 0.937 & 6.93 & 4.84 & 0.915 & 6.59 & 5.15 & 0.885 & 6.43 & 5.10 & 0.883 \\
\hline
\end{tabular}

A1: Batch A1 - standard formulation; A2: Batch A2 - standard formulation inoculated with L. monocytogenes; B1: Batch B1 - standard formulation inoculated with L. plantarum; B2: Batch B2 - standard formulation inoculated with L. plantarum and L. monocytogenes; C1: Bacth $\mathrm{C} 1$ - standard formulation added of $2 \%$ sodium lactate; $\mathrm{C} 2$ : Batch $\mathrm{C} 2$ - standard formulation added of $2 \%$ sodium lactate and inoculated with $L$. monocytogenes. 


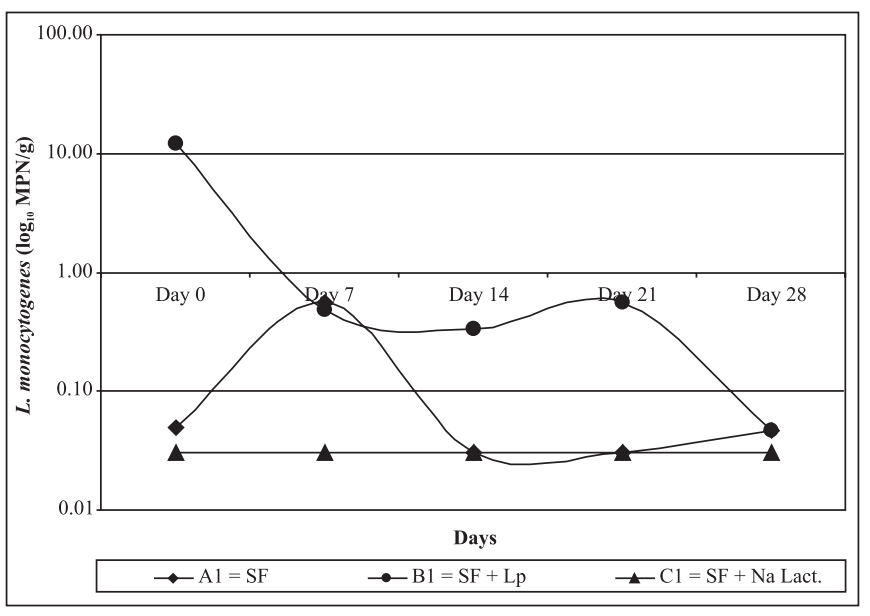

Figure 1. Survival of L. monocytogenes in naturally contaminated Italian sausages during fermentation and maturation time. $\mathrm{A} 1=\mathrm{SF}$ : Batch $\mathrm{A} 1$ - standard formulation; $\mathrm{B} 1$ $=\mathrm{SF}+\mathrm{Lp}:$ Batch B1 - standard formulation inoculated with $L$. plantarum; $\mathrm{C} 1=\mathrm{SF}+\mathrm{Na}$ Lact: $\mathrm{Bacth} \mathrm{C} 1-$ standard formulation added of $2 \%$ sodium lactate.

\section{Survival of $\mathrm{L}$. monocytogenes in experimentally contaminated samples}

The behavior of L. monocytogenes in experimentally contaminated sausages (batches A2, B2 and C2) is presented in Fig. 2. All batches presented a continual decreasing in the count curves with no significant differences between them ( $>0.05)$. The difference between the initial and the final $L$. monocytogenes counts for batches A2, B2 and C2 were 2.57 $\log , 3.81 \mathrm{log}$ and $3.3 \mathrm{log}$, respectively.

Comparing the two batches of standard formulation (A1 naturally contaminated and A2 experimentally contaminated), differences in the two L. monocytogenes count curves were noted. Batch A1, which presented a lower initial count, which increased in the first 7 days and decreased gradually afterwards. On the other hand, batch A2 with higher initial count, presented a constant decrease during the maturation time. This is probably due to the typical trait of the different strains present in each batch. While batch $\mathrm{A} 2$ was manufactured with a control strain (ATCC 7644) isolated from humans, batch A1 contained one or more native L. monocytogenes strains from raw meat or processing plants.

Batch B2, manufactured with a $L$. plantarum strain, presented a L.monocytogenes growth curve that decreased until the $14^{\text {th }}$ day, when the performance was better than in the other batches. At day 21, the L. monocytogenes counts were lower than in batches A2 and C2. Batch B2 presented the best performance if compared to batches $\mathrm{A} 2$ and $\mathrm{C} 2$, once it had the highest $L$. monocytogenes initial count and the lowest count at the end of the experiments.

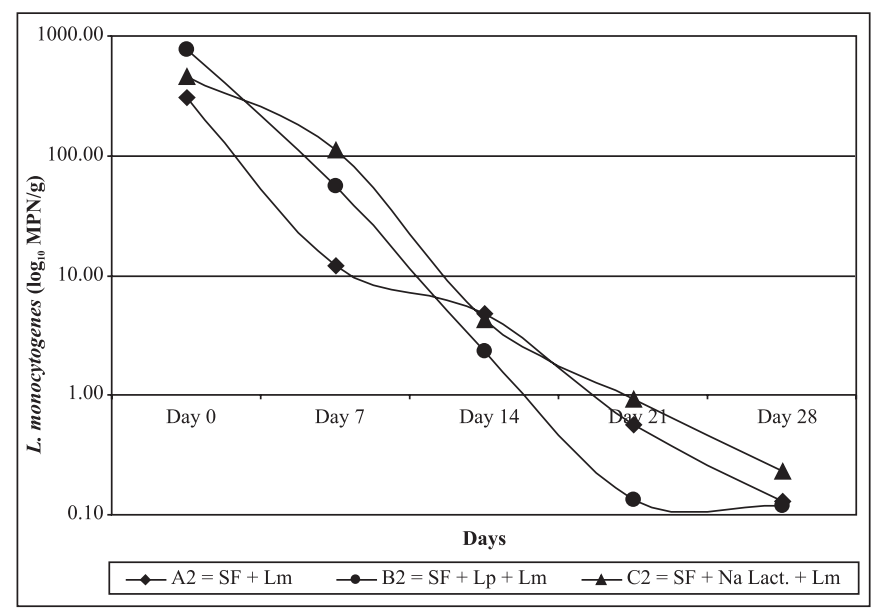

Figure 2. Survival of L. monocytogenes in experimentally contaminated Italian sausages during fermentation and maturation time. $\mathrm{A} 2=\mathrm{SF}+\mathrm{Lm}$ : Batch $\mathrm{A} 2-$ standard formulation inoculated with L. monocytogenes; B2 $=\mathrm{SF}+\mathrm{Lp}+\mathrm{Lm}$ : Batch $\mathrm{B} 2$ - standard formulation inoculated with L. plantarum and L. monocytogenes; $\mathrm{C} 2=\mathrm{SF}+\mathrm{Na}$ Lact. $+\mathrm{Lm}$ : Batch $\mathrm{C} 2$ - standard formulation added of $2 \%$ sodium lactate and inoculated with $\mathrm{L}$. monocytogenes.

The survival of $L$. monocytogenes in batch $\mathrm{C} 2$ was similar to batches $\mathrm{A} 2$ and $\mathrm{B} 2$, showing a $3.3 \log$ count reduction during the process.

Several studies have evaluated the efficiency of sausage manufacturing process in controling L. monocytogenes, and their results differ considerably $(7,8,17,18,25,29,31)$. These differences range between the efficacy of the process in decreasing and increasing $L$. monocytogenes populations and are related to the parameters used in each case (17) and the features of the strains in each experiment (29).

There are hurdles, during the manufacturing process, which could act synergically creating an inhibitory environment for the pathogens (16). In the fermentation stage, the decrease of $\mathrm{pH}$ represents an important hurdle to the growth and survival of Listeriae (29). However, in studies where LAB were not used, Chikthimmah et al. (7) and Glass \& Doyle (11) reported a growth of Listeriae at this stage. In drying and maturation stages, even at low $\mathrm{pH}$, there was a decrease of $\mathrm{A}_{\mathrm{w}}$ and an increase of salt concentration (29). In addition, the presence of bacteriocinproducing and non-bacteriocin-producing LAB cultures is another important hurdle (6).

There are many important reasons to explain $L$. monocytogenes survival during the manufacturing process and at the final product: its ability in becoming acid-resistant $(3,22)$ and, according to several studies, the effect of initial population size on the L. monocytogenes survival under stressful 
conditions $(13,14,17,18)$. This ability is related to its pathogenicity and it's usually found in strains isolated from fermented food or from meat processing facilities (35).

Under the fermentation and maturation conditions employed in this work, the decrease of L. monocytogenes counts in Italian sausage is less intense than that reported for other European studies $(8,18,31)$, where an expressive decreasing was observed at the beginning of the process. This is probably due to the lowe $\mathrm{pH}$ and higher water activity achieved in these processes. When occuring in the first days the increase of L. monocytogenes is higher than that observed in other studies (6).

Although no significant differences were detected among the three artificially contaminated batches ( $p>0.05)$, batch B2 (inoculated with $L$. plantarum) presented a slightly different reduction in counts of L. monocytogenes when compared to the standard batch (A2). The curve of the $\mathrm{C} 2$ treatment (added of sodium lactate) was very similar to the standard curve. Therefore, the use of bioprotective cultures such as Lactobacillus plantarum is highly recommended in commercial production of Italian sausages. However, the use of sodium lactate must be better evaluated, mainly when used with other inhibitory substances.

\section{ACKNOWLEDGEMENTS}

The authors are thankful to Empresas Perdigão for supporting this work, to Danisco do Brasil for donating Lactobacillus plantarum cultures and to João Degenhardt and Eduardo Degenhardt for technical assistance in sausage manufacturing.

\section{RESUMO}

\section{Sobrevivência de Listeria monocytogenes em salame tipo italiano de baixa acidez, produzido sob condições brasileiras de fabricação}

Salames têm sido considerados produtos prontos para o consumo com baixo risco de provocar listeriose devido aos obstáculos criados no processo de fabricação e suas características de $\mathrm{pH}$ e atividade água baixos, alta concentração de sal e presença de bactérias lácticas. Entretanto, a sobrevivência de Listeria monocytogenes nesta classe de produtos é verificada e estudos de processo visando à redução da contaminação por este patógeno, têm demonstrado que particularidades como variação dos parâmetros de processo, cepas de bactérias lácticas e de L. monocytogenes influenciam diretamente os resultados. Neste estudo três formulações foram avaliadas (uma padrão, uma com inoculação da cultura Lactobacillus plantarum e outra com adição $2 \%$ de lactato de sódio) empregando parâmetros de processo comumente praticados no Brasil. Os salames naturalmente contaminados apresentaram discreto aumento da população de L. monocytogenes no início do processo, seguidos por redução até o final da maturação. Os salames artificialmente contaminados tiveram redução considerável da contagem de $L$. monocytogenes não havendo diferenças significativas entre os tratamentos.

Palavras chave: Listeria monocytogenes, Lactobacillus plantarum, embutido seco fermentado, sobrevivência, salame brasileiro.

\section{REFERENCES}

1. Bacus, J. (1986). Utilization of Microrganisms in Meat Processing. Research Studies Press LTD, Letchworth. 170p.

2. Bolton, L.F.; Frank, J.F. (1999). Simple method to observe the adaptive response of Listeria monocytogenes in food. Lett. Appl. Microbiol., 29, 350-353.

3. Bonnet, M.; Montville, T.J. (2005). Acid-tolerant Listeria monocytogenes persist in a model food system fermented with nisinproducing bacteria. Lett. Appl. Microbiol., 40, 237-242.

4. BRASIL (1999). Ministério da Agricultura e do Abastecimento, Secretaria de Defesa Agropecuária. Métodos Analíticos Físico-químicos para Controle de Produtos Cárneos e seus Ingredientes - Sal e Salmoura. Instrução Normativa N N $^{\circ}$, de 21 de julho de 1999. Brasília.

5. BRASIL (2000). Ministério da Agricultura e do Abastecimento. Regulamentos Técnicos de Identidade e Qualidade de Copa, de Jerked Beef, de Presunto tipo Parma, de Presunto Cru, de Salame, de Salaminho, de Salame tipo Alemão, de Salame tipo Calabrês, de Salame tipo Friolano, de Salame tipo Napolitano, de Salame tipo Hamburguês, de Salame tipo Italiano, de Salame tipo Milano, de Lingüiça Colonial e Pepperoni. Instrução Normativa $\mathrm{N}^{\circ} 22$, de 31de julho de 2000. Brasília.

6. Campani, M.; Pedrazzoni, I.; Barbuti, S.; Baldini, P. (1993). Behaviour of Listeria monocytogenes during the maturation of naturally and artificially contaminated salami: effect of lactic-acid bactéria starter cultures. Int. J. Food Microbiol., 20(3), 169-175.

7. Chikthimmah, N.; Guyer, R.B.; Knabel, S.J. (2001) Validation of a $5-\log _{10}$ Reduction of Listeria monocytogenes following Simulated Commercial Processing of Lebanon Bologna in a model System. $J$. Food Protect., 64, 873-876.

8. Encinas, J.P.; Sanz, J.J.; García-López, M.L. Otero, A. (1999) Behaviour of Listeria spp. in naturally contaminated chorizo (Spanish fermented sausage). Int. J. Food Microbiol., 46, 167-171.

9. Farber, J.M.; Peterkin, P.I. (1991). Listeria monocytogenes, a foodborne pathogen. Micróbiol. Rev., 55, 476-511.

10. Garcia, F.T.; Gagleazzi, U.A.; Sobral, P.J.A. (2000) Variação das propriedades físicas e químicas do salame tipo Italiano durante secagem e fermentação. Braz. J. Food Technol., 3, 151-158.

11. Glass, K.A.; Doyle, M.P. (1989). Fate and thermal inactivation of Listeria monocytogenes in beaker sausage and pepperoni. J. Food Protect., 52, 226-231.

12. Incze, K. (1998) Dry Fermented Sausages. Meat Sci., 49(1), 169-177.

13. Johnson, J.L.; Doyle, M.P.; Cassens, R.G.; Shoeni, J.L. (1988). Fate of Listeria monocytogenes in tissues of experimentally infected cattle and hard salami. Appl. Environ. Microbiol., 54, 497-501.

14. Koutsoumanis, K.P.; Sofos, J.N. (2005). Effect of inoculum size on the combined temperature, $\mathrm{pH}$ and $\mathrm{a}_{\mathrm{w}}$ limits for growth of Listeria monocytogenes. Int. J. Food Microbiol., 104, 83-91.

15. Krispien, K.; Rödel, W.; Leistner, L. (1979). Vorschlag zur Berechnung der Wasseraktivität $\left(\mathrm{a}_{\mathrm{w}}-\right.$ Wert) von Fleischerzeugnissen aus den Gehalten von Wasser und Kochsalz. Fleischwirtsch 59 (8), 1173 1177 . 
16. Leistner, L. (2000). Basic aspects of food preservation by hurdle tecnology. Int. J. Food Microbiol., 55, 181-186.

17. Nightingale, K.K.; Thippareddi, H.; Phebus, R.K.; Marsden, J.L.; Nutsch, A.L. (2006). Validation of Traditional Italian-Style Salami Manufacturing Process for Control of Salmonella and Listeria monocytogenes. J. Food Protect., 69(4), 794-800.

18. Nissen, H.; Holck, A. (1998). Survival of Escherichia coli o157:H7, Listeria monocytogenes and Salmonella kentuckyin Norwegian fermented, dry sausage. Food Microbiol., 15, 273-279.

19. Ordóñez-Pereda, J.A.; Rodriguez, M.I.C.; Álvarez, L.F.; Sanz, M.L.; Minguillón, G.D.G.F.; Perales, L.H.; Cortecero, M.D.S. (2005). Tecnologia de Alimentos - Alimentos de Origem Animal. Vol. 2. Editora Artmed, São Paulo, 279p.

20. Peccio, A.; Autio, T.; Korkeala, H.; Rosmini, R.; Trevisani, M. (2003). Listeria monocytogenes occurrence and caracterization in meat-producing plants. Lett. Appl. Microbiol., 37, 234-238.

21. Phan-Thanh, L.; Mahouin, F.; Aligé, S. (2000). Acid responses of Listeria monocytogenes. Int. J. Food Microbiol., 55, 121-126.

22. Pidcock, K.; Heard, G.M.; Henrikson, A. (2002). Application of nontraditional meat starter cultures in production of Hungarian salami. Int. J. Food Microbiol., 76, 75-81.

23. Pond, T.J.; Wood, D.S.; Mumin, I.M.; Barbut, S.; Griffiths, M.W. (2001). Modeling the survival of Escherichia coli $0157: \mathrm{H} 7$ in uncooked, semidry, fermented sausage. J. Food Protect., 64(6), 759766.

24. Rodrigues, R.A.; Terra, N.N.; Fries, L.L.M. (2000). Lactato de Sódio, um conservante natural no processamento de lingüiça frescal. Higiene Alimentar, 14(75), 56-61.

25. Samelis, J.; Metaxopoulos, J.; Vlassi, M.; Pappa, A. (1998). Stability and safety of traditional Greek salami - a microbiological ecology study. Int. J. Food Microbiol., 44, 69-82.
26. Silva, N.; Junqueira, V.C.A.; Silveira, N.F.A. (1997). Manual de Métodos de Análise Microbiológica de Alimentos. Editora Livraria Varela, São Paulo, 295p.

27. Silva, W.P.; Lima. A.S.; Gandra, E.A.; Araújo, M.R.; Macedo, M.R.; Duval, E.H. (2004). Listeria spp. no processamento de lingüiça frescal em frigoríficos de Pelotas, RS, Brasil. Ciência Rural, 34(3), 911-916.

28. Terra, A.B.M.; Fries, L.L.M.; Terra, N.N. (2004). Particularidades na fabricação de salame. Livraria Varela, São Paulo, 152p.

29. Thévenot, D.; Delignette-Muller, M.L.; Christieans, S.; VernozyRozand, C. (2005a). Fate of Listeria monocytogenes in experimentally contaminated French sausages. Int. J. Food Microbiol., 101, 189200.

30. Thévenot, D.; Delignette-Muller, M.L.; Christieans, S.; VernozyRozand, C. (2005b). Prevalence of Listeria monocytogenes in 13 dried sausage processing plants and their products. Int. J. Food Microbiol., 102, 85-94.

31. Työppönen, S.; Markkula, A.; Petäjä, E.; Suihko, M.-L.; MattilaSandholm, T. (2003). Survival of Listeria monocytogenes in North European type dry sausages fermented by bioprotective meat starter cultures. Food Control, 14, 181-185.

32. U. S. FOOD AND DRUG ADMINISTRATION. (2003) Bacteriological Analitical Manual - Detection and Enumeration of Listeria monocytogenes in Foods. U.S. Departament of Health and Human services. http://www.cfsan.fda.gov/ ebam/bam-10.html

33. Varabioff, Y. (1992). Incidence ol Listeria in small goods. Lett. Appl. Microbiol., 14, 167-169.

34. Vieira, E.N.R.; Mendonça, R.C.S. (2005). Leveduras em embutidos fermentados: opção tecnológica. Revista Nacional da Carne, ed. 340. http://www.dipemar.com.br

35. Vialette, M.; Pinon, A.; Chasseignaux, E.; Lange, M. (2003). Growths kinetics of clinical and seafood Listeria monocytogenes isolates in acid and osmotic environment. Int. J. Food Microbiol., 82, 121-131. 